\title{
ROLE OF TYPE I INTERFERONS IN THE PATHOGENESIS OF BLUETONGUE VIRUS IN MICE AND RUMINANTS
}

\author{
M. Saminathan ${ }^{1}$, K.P. Singh ${ }^{2 *}$, R. Rajasekar ${ }^{1}$, Yash Pal Singh Malik ${ }^{3}$, Kuldeep Dhama ${ }^{1}$ \\ ${ }^{1}$ Division of Pathology, ICAR-Indian Veterinary Research Institute, Izatnagar, Bareilly-243122, Uttar Pradesh. \\ ${ }^{2}$ Centre for Animal Disease Research and Diagnosis (CADRAD), ICAR-Indian Veterinary Research Institute, Izatnagar, Bareilly-243122, Uttar Pradesh. \\ ${ }^{3}$ Division of Biological Standardization, ICAR-Indian Veterinary Research Institute, Izatnagar, Bareilly-243122, Uttar Pradesh.
}

Received - October 01, 2019; Revision - November 21, 2019; Accepted - December 20, 2019

Available Online - December 25, 2019

DOI: http://dx.doi.org/10.18006/2019.7(6).513.520

\section{KEYWORDS \\ Type I interferons \\ Mice \\ Ruminants \\ Pathogenesis \\ Bluetongue virus \\ Innate immunity}

\section{ABSTRACT}

Bluetongue (BT) is a non-contagious arthropod borne viral disease of domestic and wild ruminants caused by bluetongue virus (BTV), the prototype member of the genus Orbivirus, family Reoviridae. The innate immune responses are the first line of defence against viral infections. Innate immune responses are critical for development of effective adaptive immune responses. The innate immune molecules are type I IFNs (IFN- $\alpha / \beta$ ), other pro-inflammatory cytokines and chemokines, which control the viral infection. BTV is a potent type I interferon inducer in wild type mice from different tissues, cell types and host species. BTV replicates substantial fraction in conventional dendritic cells (cDCs) and plasmacytoid dendritic cells (pDCs), but only pDCs produces a significant amount of type I IFNs. A temporal relationship between viremia and IFN- $\alpha / \beta$ activity has been observed during BTV infection and IFN peak concentrations caused decreased BTV titres. Wild type adult mice with intact IFN system were neither susceptible to BTV infection nor viremia/clinical signs/lesions were observed after either intravenous or subcutaneous inoculation. Blocking of IFN- $\alpha / \beta$ activity in mice resulted in the disruption of IFN- $\alpha / \beta$-induced signaling leads to dramatically increased sensitivity to BTV, which allows the virus to replicate more efficiently.
* Corresponding author

E-mail: karam.singh@ rediffmail.com (Dr Karam Pal Singh)

Peer review under responsibility of Journal of Experimental Biology and Agricultural Sciences.

Production and Hosting by Horizon Publisher India [HPI] (http://www.horizonpublisherindia.in/).

All rights reserved.
All the articles published by Journal of Experimental Biology and Agricultural Sciences are licensed under a Creative Commons Attribution-NonCommercial 4.0 International License Based on a work at www.jebas.org.

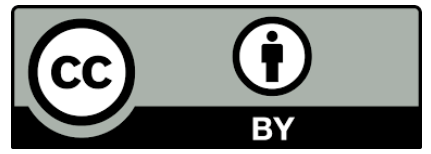




\section{Introduction}

Bluetongue (BT) is a non-contagious arthropod borne viral disease of domestic and wild ruminants caused by bluetongue virus (BTV), the prototype member of the genus Orbivirus, family Reoviridae (MacLachlan et al., 2009; Coetzee et al., 2014). BTV infection in ruminants mainly transmitted by the bite of multiple species of hematophagous biting midges (Culicoides spp.) those serve as biological vectors for BTV (Verwoerd \& Erasmus, 2004). Direct economic losses associated with BTV are high morbidity, mortality, abortions, stillbirths, foetal abnormalities, meat and fleece losses. Indirect losses are due to international trade restrictions imposed on ruminant animal movement, their germplasm, embryos, and other animal products. BTV outbreaks resulted in estimated losses of 3 billion USD/annum across the globe (Gunn et al., 2008). BTV causes severe disease in sheep; however, in cattle and goats usually show milder or sub-clinical disease. However, BTV-8 outbreaks in Europe caused severe disease in cattle and goats (Barratt-Boyes \& Maclachlan, 1995; Flanagan et al., 2008; Coetzee et al., 2014).

BTV causes severe disease in sheep characterized by pyrexia, serous to bloody nasal discharge, later on mucopurulent, oedema of lips and face, oral erosions and ulcers, cyanosis of the tongue, and lameness with hyperaemia of the coronary band (Verwoerd \& Erasmus, 2004; MacLachlan, 2004). The pathological changes are due to vascular injury resulted in tissue necrosis, hemorrhage and edema (Maclachlan et al., 2009). The BTV genome includes 10 distinct genome segments of double-stranded RNA and the gene segment encoded by 7 structural (VP1-7) and 5 non-structural (NS1-3/3A, 4) proteins (Ratinier et al., 2011). Until recently, 27 BTV serotypes have been described and the global distribution of BTV has been altered recently and resulted in emergence of novel BTV serotypes (Maan et al., 2012). Among these, 22 BTV serotypes have been reported in India. BT is now considered to be endemic in India (Prasad et al., 2009; Ranjan et al., 2015; Saminathan et al., 2016; Rao et al., 2016).

Type I interferons regulates the innate immunity and limits the replication of many viruses (Muller et al., 1994; Maclachlan et al., 2014). Type I IFNs consist of 15 subtypes of IFN- $\alpha$, one subtype of IFN- $\beta$ and one subtype of IFN- $\omega$, all were sharing a common type I IFN receptors (Theofilopoulos et al., 2005; Rodríguez-Calvo et al., 2014). Type I IFNs are secreted by all virus-infected cells in response to intracellular viral dsRNA, which is sensed by retinoic acid-inducible gene (RIG) I, RNA helicases, protein kinase dependent on RNA (PKR), and melanoma differentiation-associated gene 5 (MDA-5) (Garcia-Sastre \& Biron, 2006; Kawai \& Akira, 2006; Broquet et al., 2011; Chauveau et al., 2012). Plasmacytoid dendritic cells (pDCs) are activated by exogenous viral RNA or DNA signaling by interacting with Toll-like receptor-7 (TLR-7) or TLR-9 and produces significant amount of type I IFNs (Kawai \&
Akira, 2006; Vitour et al., 2014). Conventional dendritic cells (cDCs) and other cells are activated by viral RNA or synthetic RNA analogues like polyI:polyC to produce type I IFNs via TLR3dependent or independent mechanisms (Kawai \& Akira, 2006; Vitour et al., 2014). Production of type I IFNs by signaling with common type I IFN receptors namely IFN $\alpha \mathrm{R} 1$ and IFN $\alpha \mathrm{R} 2$ is dependent on an autocrine feedback mechanism (Clarke et al., 2001; Chauveau et al., 2012; Vitour et al., 2014). Signaling through these receptors induces the transcription of wide range of type I IFNstimulated genes (ISGs) such as 2'-5' oligoadenylate synthetases, PKR and Mx-1, which induces an antiviral state (Clarke et al., 2001; Theofilopoulos et al., 2005; Broquet et al., 2011). In addition, type I IFNs can stimulate additional molecules of innate immunity, which activates cytotoxicity of NK cells by stimulating IL-15 and IL-12 production by DCs, which in turn can activate IFN- $\gamma$ production by $\mathrm{T}$ cells and NK cells (Gautier et al., 2005; Maclachlan et al., 2014; Vitour et al., 2014).

\section{Innate immunity against BTV}

The innate immune responses are the first line of defense against viral infections. Innate immune responses are critical for the development of an effective adaptive immune responses namely, humoral and cellular immune responses. More number of cDCs are attracted in the skin following cutaneous instillation of BTV by Culicoides midges (Hemati et al., 2009; Maclachlan et al., 2014). Dendritic cells facilitate BTV replication at the site of initial infection in the skin and virus is transported to the regional lymph nodes (Barratt-Boyes \& Maclachlan, 1995; Hemati et al., 2009). Major cellular targets/ replication of BTV in the regional lymph nodes occur in dendritic cells, endothelium, macrophages, and lymphocytes (Maclachlan et al., 2009; Darpel et al., 2012). In vitro studies showed that BTV infection of ovine conventional dendritic cells from skin lymph nodes and bovine monocyte-derived macrophages leads to the production of pro-inflammatory and immune cytokines namely, interleukin (IL)-1, IL-6, IL-8, IL-12, tumour necrosis factor-alpha (TNF- $\alpha$ ), inducible nitric oxide synthetase and expression of co-stimulatory molecules that promote the proliferation of BTV-specific $\mathrm{CD} 4^{+}$and $\mathrm{CD} 8^{+} \mathrm{T}$ cells (Hemati et al., 2009). Replication of BTV in the regional lymph nodes resulted in marked cellular response characterized by increased numbers of $B$ cells in the lymphoid follicles and $\mathrm{CD}^{+} \mathrm{T}$ cells in the draining efferent lymph, and appearance of BTV-specific antibodies (BarrattBoyes \& Maclachlan, 1995; Maclachlan et al., 2014).

\section{Role of type I interferons in bluetongue viral infection}

Type I interferons (IFN-I) are a family of cytokines that have been shown to promote in vivo antiviral, antimicrobial, antitumor, and autoimmune responses. IFN-I including IFN- $\alpha$ and IFN- $\beta$ plays an essential role in the antiviral innate immune responses. Bluetongue virus is a potent inducer of IFN-I including IFN- $\alpha$ and IFN- $\beta$ in 
wild type mice without virus replication from different tissues, cell types and host species including foetal and adult leukocytes and spleen cells from sheep, endothelial cells from bovine and ovine origin, and kidney cells from rabbits, hamsters, monkeys, cats, and pigs (Jameson et al., 1978; Vitour et al., 2014). Although BTV replicates substantial fraction in conventional dendritic cells (cDCs) and pDCs, only pDCs produces significant amount of IFN$\alpha$ and $-\beta$. Importantly, BTV was shown to induce the IFN production in multiple human cells with a high efficiency, particularly in tumour-derived cell lines. Jameson et al. (1978) reported that BTV was 5 to 10 times more potent IFN inducer (600,000 units/ml of plasma) after 8 hours post infection (hpi) when compared to other viral agents. Both attenuated and virulent strains and many serotypes can induce IFNs (Maclachlan et al., 2014; Ortego et al., 2014; Vitour et al., 2014).

The dsRNA viruses were detected by toll-like receptors on type I IFN producing cells (mostly notably pDCs). Secreted IFNs bind to the type I IFN receptors (IFNAR) on the surface of neighbouring cells, activating the Janus kinase (Jak)/signal transducer and activator of transcription (STAT) signaling pathways (Broquet et al., 2011; Sen et al., 2011). This in turn induces the transcriptional activation of target genes, which render the cells resistant to virus replication through various mechanisms, including degradation of viral mRNAs, inhibition of viral translation, and inhibition of cell growth (Uddin et al., 1995). In addition, the RIG-I-like Receptor (RLR) signaling pathway controls both the sensing and antiviral response to BTV in non-hematopoietic target cells (Qin et al., 2011; Vitour et al., 2014).

The IFN levels were detectable as soon as 4 hpi and maximum levels were detected between 8 and 12 hpi and then decreased to undetectable levels at 24 hpi (Chauveau et al., 2012). The IFN- $\alpha / \beta$ levels were detected in the blood of sheep inoculated with BTV-8 at 2 and 6 days post infection (dpi). The BTV titres in the blood were higher when IFN was no longer detectable in serum (Russell et al., 1996). These results suggested the preponderant role of IFN in the initial antiviral response rather than involvement in the subsequent elimination of the infection (Foster et al., 1991). A temporal relationship between viremia and IFN- $\alpha / \beta$ activity has been observed in sheep infected with BTV, where IFN peak concentrations induced approximately a $90 \%$ decrease in virus titre occurs (Foster et al., 1991). In comparison to the IFN antiviral response detected in cattle, the IFN response in sheep was higher and lasted longer (Calvo-Pinilla et al., 2009a; Calvo-Pinilla et al., 2010; Ortego et al., 2014; Marín-López et al., 2016).

\section{Constraints of animal models for studying the BTV pathogenesis}

Natural hosts like sheep and cattle are suitable model to study the pathogenesis, virulence, host-pathogen interaction, and testing of vaccines against BTV experimentally (MacLachlan et al., 2009; Coetzee et al., 2014). However, drawbacks are expensive, time consuming, stringent ethical issues, inclusion of less number of animals during experimentation, difficult in getting BTV seronegative animals, and require specialized housing facilities with biosafety level-3 (Bowen et al., 1982; Coetzee et al., 2014; Ortego et al., 2014). To solve these critical issues, establishment of an efficient alternative laboratory animal model especially adult mice model is necessary. The advantages of adult mice are easy availability, manageability, and well-known knowledge of its immune system and genetics (Calvo-Pinilla et al., 2009a; CalvoPinilla et al., 2009b; Calvo-Pinilla et al., 2010; Ortego et al., 2014; Marín-López et al., 2016).

Suckling mice have been used as a model for studying the pathogenesis of BTV-induced cerebral malformations of bovine and ovine foetuses (Richards \& Cordy, 1967; Narayan \& Johnson, 1972). BTV infection in newborn mice via intracerebral (I/C) route leads to severe cerebral lesions, which do not resemble the hemorrhagic, immunosuppressive, and respiratory lesions observed during BT infection in natural host (CalvoPinilla et al., 2009a; Calvo-Pinilla et al., 2009b, Calvo-Pinilla et al., 2010; Marín-López et al., 2016). For years, different groups have tried to establish a laboratory animal model to facilitate the studies of pathogenesis, immune response and vaccination against BTV. The cost of testing new vaccines in target species is high and is a major obstacle for laboratories and industries. Experimental studies showed that BTV grew faster in 1-day-old suckling mice inoculated (I/C) than at 2 weeks of age (Narayan \& Johnson, 1972). Infection with BTV in 2-week-old mice resulted in limited multiplication leads to mild disease, and infection in 4-week-old mice did not cause clinical disease due to no viral multiplication (Narayan \& Johnson, 1972). We found that wild type adult mice with intact IFN system were neither susceptible to BTV infection nor viremia/clinical signs/lesions were observed after either intravenous (I/V) or subcutaneous (S/C) inoculation (Saminathan et al., 2018). We have assessed the influence of various factors in establishment of BTV infection in mice like age of the host, dose of the virus, route of inoculation, and type I IFNs (Saminathan et al., 2018). BTV induced lesions in mice vary with age of the host suggesting that susceptibility is influenced by the stage of immunological maturity of the host (Richards \& Cordy, 1967). It was reported that possible limitation for establishment of BTV infection in adult mice could be the innate immune responses characterized by abnormally excessive levels of type I IFNs production after BTV infection by the host and causes brief and strong antiviral state. After type I IFNs peak, no virus was detected from blood and spleen (Saminathan et al., 2018). BTV is a potent type I interferon (IFN- $\alpha$ and IFN- $\beta$ ) inducer in wild type mice (Jameson et al., 1978; Vitour et al., 2014). 


\section{IFNAR ${ }^{(--)}$mice as a model to study viral infections}

Mice are an ideal species for studying the pathogenesis of infectious diseases (Bowen et al., 1982; Calvo-Pinilla et al., 2009a; Calvo-Pinilla et al., 2009b; Calvo-Pinilla et al., 2010; Caporale et al., 2011). Unfortunately, immunocompetent wild-type mice are not susceptible to many viruses having high pathogenic potential, and thus alternative strategies are needed (Caporale et al., 2011; Saminathan et al., 2018). Transgenic mice lacking the IFN-I receptors (IFNAR ${ }^{--}$) were completely unresponsive to the antiviral action of natural murine type I IFNs. Ablated type I IFN immune responses in $\operatorname{IFNAR}^{(--)}$mice resulted in enhanced susceptibility to many viruses including vesicular stomatitis virus, Semliki Forest virus, vaccinia virus, lymphocytic choriomeningitis virus, influenza virus subtypes, severe acute respiratory syndrome coronavirus, and Rift Valley fever virus with higher viral antigen titers and mortality even at lower doses compared to wild-type mice (Calvo-Pinilla et al., 2009a; Calvo-Pinilla et al., 2010; Ortego et al., 2014; Marín-López et al., 2016; Wong \& Qiu, 2018).

Blocking of IFN- $\alpha / \beta$ activity in mice leads to increased sensitivity to many viruses. Mice lacking the type I IFN receptors $\left[\operatorname{IFNAR}^{(-/-)}\right]$were generated to elucidate the physiological role of type I IFN system by Muller et al. (1994). Comparative cytofluorometry analysis revealed that no abnormalities in the major lymphocyte subsets like expression of CD3, CD4, and CD8 in thymocytes and splenocytes and major histocompatibility complex class I and class II antigens in thymocytes, splenocytes, and peritoneal macrophages. The lack of type I IFN system allows the virus to replicate more efficiently and $\operatorname{IFNAR}^{(--)}$mice have been used as a laboratory animal model to study the immune response, determinants of virulence, vaccine development, and pathogenicity of various viruses like human $\mathrm{T}$ cell leukemia virus (Delebecque et al., 2005), Crimean-Congo hemorrhagic fever virus (Zivcec et al., 2013), West Nile virus (Winkelmann et al., 2012), Schmallenberg virus (Wernike et al., 2012), poliovirus (Ohka et al., 2007), measles virus (Volker et al., 2013), Theiler's virus, hepatitis viruses (Chen et al., 2013), Rift valley fever virus (Lorenzo et al., 2010), influenza virus, Zika virus (Winkler \& Peterson, 2018), bluetongue virus, etc. (Calvo-Pinilla et al., 2009a; Calvo-Pinilla et al., 2009b; Calvo-Pinilla et al., 2010; Ortego et al., 2014; Marín-López et al., 2016; Wong \& Qiu, 2018)

\section{Interferon $\alpha / \beta$ receptor knockout $\left(\right.$ IFNAR $^{-/-}$) mice as a model to study BTV infection}

$\operatorname{IFNAR}^{(-/-)}$mice have been used as a laboratory animal model to study the immune response, determinants of virulence, vaccine development, and pathogenicity of many viruses (Calvo-Pinilla et al., 2009a; Calvo-Pinilla et al., 2009b; Calvo-Pinilla et al., 2010; Caporale et al., 2011). Blocking of IFN $\alpha / \beta$ activity in mice leads to dramatically increased susceptibility to many viruses. Blocking of IFN- $\alpha / \beta$ activity in mice resulted in the disruption of IFN- $\alpha / \beta$-induced signaling, which is an important determinant of the tissue tropism and pathogenicity of BTV and unable to establish an antiviral state leads to a dramatically increased sensitivity to BTV, which allows the virus to replicate more efficiently (Ortego et al., 2014; Vitour et al., 2014; Wong \& Qiu, 2018). Calvo-Pinilla et al. (2009a) and Ortego et al. (2014) characterized a IFN- $\alpha / \beta$ receptors deficient $\left[\right.$ IFNAR $^{(-/)}$] mice model to study the BTV serotypes.

The IFNAR ${ }^{(--)}$mice were susceptible to many serotypes of BTV-1, -4 and -8 showed clinical signs of ocular discharges, apathy and disease progression led to animal death. BTV was recovered from spleen, lungs, thymus, lymph nodes, and blood (Calvo-Pinilla et al., 2009a; Calvo-Pinilla et al., 2009b; Ortego et al., 2014). The differential virulence of serotypes of BTV-1, 4, and 8 was maintained in IFNAR $^{(--)}$mice model as that of natural host like sheep and cattle (Ortego et al., 2014; Vitour et al., 2014). The $\operatorname{IFNAR}^{(--)}$mice could be an adequate laboratory animal model to study differences in virulence among BTV serotypes (CalvoPinilla et al., 2009a; Ortego et al., 2014; Vitour et al., 2014; Wong \& Qiu, 2018).

BTV-8 has the ability to infect IFNAR $^{(--)}$mice by oral route and IFNAR $^{(--)}$mice can be a good model to study routes of BTV transmission (Calvo-Pinilla et al., 2010). Ortego et al. (2014) analyzed whether up-regulation of pro-inflammatory cytokines described in ruminants infected with BTV correlates with an induction of these cytokines in the IFNAR ${ }^{(--)}$mice infected with BTV-4, even though their innate immune response is compromised. IFNAR ${ }^{(--)}$mice developed strong pro-inflammatory immune responses following BTV-4 infection. The maximum concentration of cytokines in serum correlates with gross pathological alterations characterized by widespread edema, hemorrhages in spleen and lungs, and enlarged spleen and lymph nodes (Calvo-Pinilla et al., 2009a, Calvo-Pinilla et al., 2010; Marín-López et al., 2016). The histopathological examination of IFNAR $^{(--)}$mice infected with BTV-4 showed similar pathological alterations compared to BTV infected ruminants (MacLachlan et al., 2009) and this animal model could be a useful tool to study the pathogenesis produced by BTV. Several studies have shown that adult IFNAR ${ }^{(--)}$mice serve as a good animal model to test BTV vaccines (Calvo-Pinilla et al., 2009a; Ortego et al., 2014; Vitour et al., 2014; Wong \& Qiu, 2018).

\section{Disadvantages of INF- $\alpha / \beta$ receptor knockout $\left(\operatorname{IFNAR}^{-/-}\right)$mice}

IFNAR $^{(--)}$mice are highly susceptible to BTV-1, BTV-4 and BTV8 infection. But disadvantages of this mice model are higher mortality within few days after infection. IFNAR ${ }^{(--)}$mice infected I/V with $10^{6}$ PFUs of BTV-4 resulted in mortality within 60 hpi and low infectious doses $\left(10^{3}\right.$ or $10^{4} \mathrm{PFU}$ of BTV) mice died at 6 
dpi. BTV-8 (10 3 PFU) infection resulted in mortality within 4-5 dpi, $10^{2}$ PFU at 5-6 dpi, and even $10^{1}$ PFU caused mortality at 7 dpi. BTV-1 ( $10^{3}$ PFU) infection resulted in mortality within 4 dpi, $10^{2} \mathrm{PFU}$ at 5 dpi and $10^{1} \mathrm{PFU}$ at 6 dpi (Calvo-Pinilla et al., 2009a; Ortego et al., 2014). Marín-López et al. (2016) inoculated S/C with $10^{4} \mathrm{pfu}$ of BTV-4 resulted in mortality at $72 \mathrm{hpi}$ and $10^{2} \mathrm{pfu}$ killed at 5 dpi. Even, orally infected animals with $10^{6}$ PFU of BTV-8 died between 4 to 8 dpi (Calvo-Pinilla et al., 2010).

Further, limitations of this mice model are limited availability, costly, may require specialised housing, susceptible to other pathogens, and produces abnormally severe disease. Because of high mortality, difficult to study humoral (seroconversion and neutralizing antibodies) and cell mediated immune responses, primary and secondary (memory) immune responses to BTV, infection kinetics/clinical courses, and host-pathogen interaction (Wong \& Qiu, 2018). IFNAR ${ }^{(-)}$mice have defective innate immune responses that lead to impaired adaptive immunity. Hence they are not good animal models for studying antiviral compounds, particularly vaccines (Züst et al., 2014).

\section{Immunocompetent wild-type mice as a model to study BTV infection after selective blockade of type I IFNs}

It has been challenging to infect adult immunocompetent mice with BTV and viral replication is readily aborted by the innate immune response (Caporale et al., 2011; Saminathan et al., 2018). An immunocompetent mouse model of BTV infection that more closely reflects the ruminant disease could improve our understanding of the pathogenesis of BTV and ensuing host immune response, and have greater utility for evaluating vaccines and therapeutics (Lopez-Gil et al., 2013; Vermillion et al., 2017; Gorman et al., 2018; Nazerai et al., 2018).

Recently, a study was conducted to solve these critical issues by establishing a mouse model of BTV infection by selective blockade of interferon- $\alpha / \beta$ receptors temporarily (Saminathan et al., 2019). The advantages of this mouse model are readily available, temporarily induced immune deficiency, more virus replication, produced natural disease, reversion of host to wild type with normal immune response, and recapitulates as that of IFNAR

${ }^{l-)}$ mice. Recently, adult mice with type I interferon gene blockade have been used as a model to study the lethal Zika virus, vesicular stomatitis virus, and West Nile virus infections (Sheehan et al., 2006; Sheehan et al., 2015; Gorman et al., 2018; Nazerai et al., 2018). This model might be useful for studying the BTV virulence, pathogenesis, transmission, host-virus interaction, and immune response against BTV rather than mortality. Further, this mice model would be useful for testing the protective efficacy of new BTV vaccines, because testing of new vaccines in natural host species is a major limitation. Recently, sequential pathology was investigated, virological and immunological responses in IFNAR- blocked mice infected with BTV-1. As far as the author's knowledge, this study constitutes the first detailed characterization of such changes in IFNAR1-blocked mice infected with BTV-1 (Saminathan et al., 2019).

Administration of anti-mouse interferon $\alpha / \beta$ receptor (IFNAR1 subunit) monoclonal antibody (clone: MAR1-5A3) intraperitoneally, resulted in selective blockade of type I IFN signal transduction and establishment of BTV-1 infection in the adult mouse. Mouse anti-mouse IFNAR1 recognizes the extracellular domain of the IFNAR1 subunit of the mouse IFN $\alpha / \beta$ receptor. The antibody blocks IFNAR1 signaling both in vitro and in vivo without depleting IFNAR1 bearing cells. For in vivo blocking functional studies, a large loading dose of $2.5 \mathrm{mg} / \mathrm{mouse}$ is required to saturate all the binding sites in vivo and then to maintain a high enough level to keep them saturated. Then a weekly dose of $0.5 \mathrm{mg} /$ mouse should be administered if required. The half-life of mouse anti-mouse IFNAR1 following $2.5 \mathrm{mg}$ loading dose is about 5 days and the half-life of low dose of $250 \mu \mathrm{g}$ is 1.5 days, but this is not sufficient to saturate the receptors in mouse (Sheehan et al., 2006; Sheehan et al., 2015; Pinto et al., 2011; Govero et al., 2016; Smith et al., 2017).

It was reported that IFNAR-blocked mice were susceptible to BTV infection and showed increased susceptibility, clinical signs and BTV RNA was detected in various tissues (Saminathan et al., 2019). The clinical manifestations were similar to the earlier findings in $\operatorname{IFNAR}^{(-)}$mice. In our study, lower rate of mortality was observed at prolonged intervals when compared to early mortality and abnormally severe clinical disease in $\operatorname{IFNAR}^{(--)}$mice infected with BTV-1, BTV-4 and BTV-8 (Calvo-Pinilla et al., 2009a; Calvo-Pinilla et al., 2009b; Calvo-Pinilla et al., 2010; Ortego et al., 2014; Vitour et al., 2014; Marín-López et al., 2016; Saminathan et al., 2019).

\section{Conclusion}

The mechanisms responsible for the production of type I IFNs in response to BTV infection are still not completely understood. Immunocompromised $\operatorname{IFNAR}^{(--)}$mice have been shown to be a very good alternative laboratory animal model for studying the pathogenesis of viruses that do not cause disease in immunocompetent wild-type mice. It is obvious that advent of IFNAR $^{(--)}$mice significantly assisted the researchers to easily and rapidly study the new pathogens during a potential outbreak situation. Selective blockade of type I IFN signals using antimouse IFNAR1 monoclonal antibody (clone: MAR1-5A3) in immunocompetent wild-type mice with intact IFN immune system could be a good animal model to study bluetongue virus pathogenesis and to evaluate vaccine strategies against BTV when compared to IFNAR $^{(--)}$mice. IFNAR1-blocked BTV infected mice showed clinical signs, disease progression, and pathology as 
that of BT in ruminants. IFNAR ${ }^{(-)}$mice have defective innate immune responses which lead to impaired adaptive immunity and they are not good animal models for studying antiviral compounds, particularly vaccines. IFNAR ${ }^{(-)}$use in research requires careful interpretation of results due to differences in the immunological state between wild-type and $\operatorname{IFNAR}^{(--)}$mice, and in the biology between mice and ruminants.

\section{Conflict of Interest}

The authors declare that there is no conflict of interest.

\section{References}

Barratt-Boyes SM, Maclachlan NJ (1995) Pathogenesis of bluetongue virus infection of cattle. Journal of the American Veterinary Medical Association 206: 1322-1329.

Bowen RA, Howard TH, Pickett BW (1982) Interaction of bluetongue virus with preimplantation embryos from mice and cattle. American Journal of Veterinary Research 43: 1907-1911.

Broquet AH, Hirata Y, McAllister CS, Kagnoff MF (2011) RIGI/MDA5/MAVS are required to signal a protective IFN response in rotavirus-infected intestinal epithelium. Journal of Immunology 186: $1618-1626$.

Calvo-Pinilla E, Nieto JM, Ortego J (2010) Experimental oral infection of bluetongue virus serotype 8 in type I interferon receptordeficient mice. Journal of General Virology 91: 2821-2825.

Calvo-Pinilla E, Rodriguez-Calvo T, Anguita J, Sevilla N, Ortego J (2009a) Establishment of a bluetongue virus infection model in mice that are deficient in the alpha/beta interferon receptor. PLoS One 4: e5171.

Calvo-Pinilla E, Rodriguez-Calvo T, Sevilla N, Ortego J (2009b) Heterologous prime boost vaccination with DNA and recombinant modified vaccinia virus Ankara protects IFNAR $^{(-/)}$mice against lethal bluetongue infection. Vaccine 28: 437-445.

Caporale M, Wash R, Pini A, Savini G, Franchi P, Golder M, Patterson-Kane J, Mertens P, Di Gialleonardo L, Armillotta G, Lelli R, Kellam P, Palmarini M (2011) Determinants of bluetongue virus virulence in murine models of disease. Journal of Virology 85: 11479-11489.

Chauveau E, Doceul V, Lara E, Adam M, Breard E, Sailleau C, Viarouge C, Desprat A, Meyer G, Schwartz-Cornil I, Ruscanu S, Charley B, Zientara S, Vitour D (2012) Sensing and control of bluetongue virus infection in epithelial cells via RIG-I and MDA5 helicases. Journal of Virology 86 : 11789-11799.

Chen MF, Lin Y, Xia YC, Sun C, Feng XM, Lu MJ, Yang DL, Wu J (2013) Establishment and application of hepatitis B virus persistent replication model in $\operatorname{IFNAR}^{(--)}$mouse. Journal of Huazhong University of Science and Technology [Medical Sciences] 33: 392-397.

Clarke CJ, Trapani JA, Johnstone RW (2001) Mechanisms of interferon mediated anti-viral resistance. Current Drug Targets Immune. Endocrine \& Metabolic Disorders 1: 117-130.

Coetzee P, van Vuuren M, Venter EH, Stokstad M (2014) A review of experimental infections with bluetongue virus in the mammalian host. Veterinary Research 182: 21-34.

Darpel KE, Monaghan P, Simpson J, Anthony SJ, Veronesi E, Brooks HW, Elliot H, Brownlie J, Takamatsu HH, Mellor PS, Mertens PP (2012) Involvement of the skin during bluetongue virus infection and replication in the ruminant host. Veterinary Research 43: 40.

Delebecque F, Combredet C, Gabet AS, Wattel E, Brahic M, Tangy F (2005) A chimeric human T cell leukemia virus type I bearing a deltaR Moloney-murine leukemia virus envelope infects mice persistently and induces humoral and cellular immune responses. Journal of Infectious Diseases 191: 255-263.

Flanagan M, Johnson SJ, Hoffmann D, Polkinghorne IG, Reid DJ, Shepherd MA (2008) Clinical pathology of Australian bluetongue virus serotype 16 infection in Merino sheep. Australian Veterinary Journal 70: 101-04.

Foster NM, Luedke AJ, Parsonson IM, Walton TE (1991) Temporal relationships of viremia, interferon activity, and antibody responses of sheep infected with several bluetongue virus strains. American Journal of Veterinary Research 52: 192-196.

Garcia-Sastre A, Biron CA (2006) Type 1 interferons and the virus-host relationship: a lesson in detente. Science 312: 879-882.

Gautier G, Humbert M, Deauvieau F, Scuiller M, Hiscott J, Bates EE, Trinchieri G, Caux C, Garrone P (2005) A type I interferon autocrine-paracrine loop is involved in Toll-like receptor induced interleukin-12p70 secretion by dendritic cells. Journal of Experimental Medicine 201: 1435-1446.

Gorman MJ, Caine EA, Zaitsev K, Begley MC, Weger-Lucarelli J, Uccellini MB, Tripathi S, Morrison J, Yount BL, Dinnon KH 3rd, Rückert C, Young MC, Zhu Z, Robertson SJ, McNally KL, Ye J, Cao B, Mysorekar IU, Ebel GD, Baric RS, Best SM, Artyomov MN, Garcia-Sastre A, Diamond MS (2018) An immunocompetent mouse model of Zika virus infection. Cell Host Microbe 23: 672-685.

Govero J, Esakky P, Scheaffer SM, Fernandez E, Drury A, Platt DJ, Gorman MJ, Richner JM, Caine EA, Salazar V, Moley KH, Diamond MS (2016) Zika virus infection damages the testes in mice. Nature 540: 438-442. 
Gunn G, Stott A, Toma L, Weldegebriel H, Moran D, Fofana A, Purse B, Blackwell A (2008) Assessing the economic impact of different bluetongue virus (BTV) incursion scenarios in Scotland. Supplementary technical report for an extra response scenario: $80 \%$ vaccine uptake across all Scotland. Edinburgh: Scottish Government, Pp. 86.

Hemati B, Contreras V, Urien C, Bonneau M, Takamatsu HH, Mertens PP, Breard E, Sailleau C, Zientara S, Schwartz-Cornil I (2009) Bluetongue virus targets conventional dendritic cells in skin lymph. Journal of Virology 83: 8789-8799.

Jameson P, Schoenherr CK, Grossberg SE (1978) Bluetongue virus, an exceptionally potent interferon inducer in mice. Infection and Immunity 20: 321-323.

Kawai T, Akira S, (2006) Innate immune recognition of viral infection. Nature Immunology 7: 131-137.

Lopez-Gil E, Lorenzo G, Hevia E, Borrego B, Eiden M, Groschup M, Gilbert SC, Brun A (2013) A single immunization with MVA expressing $\mathrm{GnGc}$ gly-coproteins promotes epitope-specific $\mathrm{CD} 8^{+}-\mathrm{T}$ cell activation and protects immune-competent mice against a lethal RVFV infection. PLOS Neglected Tropical Diseases 7: e2309.

Lorenzo G, Martin-Folgar R, Hevia E, Boshra H, Brun A (2010) Protection against lethal Rift valley fever virus (RVFV) infection in transgenic $\operatorname{IFNAR}^{(--)}$mice induced by different DNA vaccination regimens. Vaccine 28: 2937-2944.

Maan NS, Maan S, Belaganahalli MN, Ostlund EN, Johnson DJ, Nomikou K, Mertens PP (2012) Identification and differentiation of the twenty six blue-tongue virus serotypes by RT-PCR amplification of the serotype-specific genome segment 2. PloS One 7: e32601.

MacLachlan NJ (2004) Bluetongue: pathogenesis and duration of viraemia. Veterinaria Italiana 40: 462-467.

MacLachlan NJ, Drew CP, Darpel KE, Worwa G (2009) The pathology and pathogenesis of bluetongue. Journal of Comparative Pathology 141: 1-16.

Maclachlan NJ, Henderson C, Schwartz-Cornil I, Zientara S (2014) The immune response of ruminant livestock to bluetongue virus: from type I interferon to antibody. Virus Research182: 71-7.

Marín-López A, Bermúdez R, Calvo-Pinilla E, Moreno S, Brun A, Ortego J (2016) Pathological characterization of $\operatorname{IFNAR}^{(--)}$mice infected with bluetongue virus serotype 4. International Journal of Biological Sciences 12: 1448-1460.

Muller U, Steinhoff U, Reis LF, Hemmi S, Pavlovic J, Zinkernagel RM, and Aguet, M (1994) Functional role of type I and type II interferons in antiviral defense. Science 264:1918-1921.
Narayan O, Johnson RT (1972) Effects of viral infection on nervous system development. I. Pathogenesis of bluetongue virus infection in mice. American Journal of Pathology 168: 1-14.

Nazerai L, Schøller AS, Rasmussen POS, Buus S, Stryhn A, Christensen JP and Thomsen AR (2018) A new in vivo model to study protective immunity to Zika Virus infection in mice with intact type I interferon signaling. Frontiers in Immunology 9: 593.

Ohka S, Igarashi H, Nagata N, Sakai M, Koike S, Nochi T, Kiyono $\mathrm{H}$, Nomoto A (2007) Establishment of a poliovirus oral infection system in human poliovirus receptor-expressing transgenic mice that are deficient in alpha/beta interferon receptor. Journal of Virology 81: 7902-7912.

Ortego J, de la Poza F, Marín-López A (2014) Interferon $\alpha / \beta$ receptor knockout mice as a model to study bluetongue virus infection. Virus Research 182: 35-42.

Pinto AK, Daffis S, Brien JD, Gainey MD, Yokoyama WM, Sheehan KC, Murphy KM, Schreiber RD, Diamond MS (2011) A Temporal Role of type I interferon signaling in $\mathrm{CD}^{+} \mathrm{T}$ cell maturation during acute West Nile virus infection. PLOS Pathogens 7: e1002407.

Prasad G, Sreenivasulu D, Singh KP, Mertens PPC, Maan S (2009) Bluetongue in the Indian subcontinent. In: Mellor P, Baylis M, Mertens P (Eds.), Bluetongue. Elsevier, Amsterdam, Netherlands. p. 167-189

Qin L, Ren L, Zhou Z, Lei X, Chen L, Xue Q, Liu X, Wang J, Hung $T$ (2011) Rotavirus nonstructural protein 1 antagonizes innate immune response by interacting with retinoic acid inducible gene I. Virology Journal 8: 526.

Ranjan K, Minakshi P, Prasad G (2015) Bluetongue: Indian perspective. Acta virologica 59: 317-37.

Rao PP, Hegde NR, Reddy YN, Krishnajyothi Y, Reddy YV, Susmitha B, Gollapalli SR, Putty K, Reddy GH (2016) Epidemiology of Bluetongue in India. Transboundary and Emerging Diseases 63: e151-64.

Ratinier M, Caporale M, Golder M, Franzoni G, Allan K, Nunes SF, Armezzani A, Bayoumy A, Rixon F, Shaw A, Palmarini M (2011) Identification and characterization of a novel non-structural protein of bluetongue virus. PLoS Pathogens 7: e1002477.

Richards WVC, Cordy DR (1967) Bluetongue virus infection: pathologic responses of nervous systems in sheep and mice. Science 156: 530-531.

Rodríguez-Calvo T, Rojas JM, Martín V, Sevilla N (2014) Type I interferon limits the capacity of bluetongue virus to infect hematopoietic precursors and dendritic cells in vitro and in vivo. Journal of Virology 88: 859-67. 
Russell H, O’Toole DT, Bardsley K, Davis WC, Ellis JA (1996) Comparative effects of bluetongue virus infection of ovine and bovine endothelial cells. Veterinary Pathology 33: 319-331.

Saminathan M, Rana R, Ramakrishnan MA, Karthik K, Malik YS, Dhama K (2016) Prevalence, diagnosis, management and control of important diseases of ruminants with special reference to Indian scenario. Journal of Experimental Biology and Agricultural Sciences 4: $338-367$.

Saminathan M, Singh KP, Vineetha S, Maity M, Biswas SK, Reddy GBM, Milton AAP, Chauhan HC, Chandel BS, Ramakrishnan MA, Gupta VK (2018) Factors determining the clinical outcome of bluetongue virus infection in adult mice. Indian Journal of Veterinary Pathology 42: 239-248.

Saminathan M, Singh KP, Vineetha S, Maity M, Biswas SK, Reddy GBM, Chauhan HC, Milton AAP, Ramakrishnan MA, Maan S, Maan NS, Hemadri D, Chandel BS, Gupta VK, Mertens PPC (2019) Virological, immunological and pathological findings of transplacentally transmitted bluetongue virus serotype 1 in IFNAR1-blocked mice during early and mid gestation. Scientific Reports (Accepted).

Sen A, Pruijssers AJ, Dermody TS, García-Sastre A, Greenberg HB (2011) The early interferon response to rotavirus is regulated by PKR and depends on MAVS/IPS-1, RIG-I, MDA-5, and IRF3. Journal of Virology 85: 3717-3732.

Sheehan KC, Lai KS, Dunn GP, Bruce AT, Diamond MS, Heutel JD, Dungo-Arthur C, Carrero JA, White JM, Hertzog PJ, Schreiber RD (2006) Blocking monoclonal antibodies specific for mouse IFN-alpha/beta receptor subunit 1 (IFNAR-1) from mice immunized by in vivo hydrodynamic transfection. Journal of Interferon \& Cytokine Research 26: 804-819.

Sheehan KC, Lazear HM, Diamond MS, Schreiber RD (2015) Selective blockade of interferon- $\alpha$ and $-\beta$ reveals their nonredundant functions in a mouse model of West Nile virus infection. PLoS One 10: e0128636.

Smith DR, Hollidge B, Daye S, Zeng X, Blancett C, Kuszpit K, Bocan T, Koehler JW, Coyne S, Minogue T, Kenny T, Chi X, Yim S, Miller L, Schmaljohn C, Bavari S, Golden JW (2017) Neuropathogenesis of Zika Virus in a highly susceptible immunocompetent mouse model after antibody blockade of type I interferon. PLOS Neglected Tropical Diseases 11: e0005296.

Theofilopoulos AN, Baccala R, Beutler B, Kono DH (2005) Type I interferons (alpha/beta) in immunity and autoimmunity. Annual Review of Immunology 23: 307-336.
Uddin S, Chamdin A, Platanias LC (1995) Interaction of the transcriptional activator Stat-2 with the type I interferon receptor Journal of Biological Chemistry 270: 24627-24630.

Vermillion MS, Lei J, Shabi Y, Baxter VK, Crilly NP, McLane M, Griffin DE, Pekosz A, Klein SL, Burd I (2017) Intrauterine Zika virus infection of pregnant immunocompetent mice models transplacental transmission and adverse perinatal outcomes. Nature Communications 8:14575.

Verwoerd DW, Erasmus BJ (2004) Bluetongue. In: Coetzer JA, Tustin RC (Eds.), Infectious Diseases of Livestock., $2^{\text {nd }}$ ed. Oxford Press, Cape Town, Pp. 1201-1220.

Vitour D, Doceul V, Ruscanu S, Chauveau E, Schwartz-Cornil I, Zientara S (2014) Induction and control of the type I interferon pathway by bluetongue virus. Virus Research 182: 59-70.

Volker I, Bach P, Coulibaly C, Plesker R, Abel T, Seifried J, Heidmeier S, Muhle-bach MD, Lauer UM, Buchholz CJ (2013) Intrahepatic application of suicide gene-armed measles virotherapeutics: a safety study in transgenic mice and rhesus macaques. Human Gene Therapy Clinical Development 24: 11-22.

Wernike K, Breithaupt A, Keller M, Hoffmann B, Beer M, Eschbaumer M (2012) Schmallenberg virus infection of adult type I interferon receptor knock-out mice. PLoS ONE 7: e40380.

Winkelmann ER, Widman DG, Xia J, Ishikawa T, Miller-Kittrell M, Nelson MH, Bourne N, Scholle F, Mason PW, Milligan GN (2012) Intrinsic adjuvanting of a novel single-cycle flavivirus vaccine in the absence of type I interferon receptor signaling. Vaccine 30: 1465-1475.

Winkler CW, Peterson KE (2018) Using immunocompromised mice to identify mechanisms of Zika virus transmission and pathogenesis. Immunology 153: 443-454.

Wong G, Qiu XG (2018) Type I interferon receptor knockout mice as models for infection of highly pathogenic viruses with outbreak potential. Zoological Research 39: 3-14.

Ziveec M, Safronetz D, Scott D, Robertson S, Ebihara H, Feldmann H (2013) Lethal Crimean-Congo hemorrhagic fever virus infection in interferon alpha/beta receptor knockout mice is associated with high viral loads, proinflammatory responses, and coagulopathy. Journal of Infectious Diseases 207: 1909-1921.

Züst R, Toh YX, Valdés I, Cerny D, Heinrich J, Hermida L, Marcos E, Guillén G, Kalinke U, Shi PY, Fink K (2014) Type I interferon signals in macrophages and dendritic cells control dengue virus infection: implications for a new mouse model to test dengue vaccines. Journal of Virology 88: 7276-7285. 